DOI: $\square$ https://doi.org/10.15407/techned2020.04.067

\title{
REDUCING ADDITIONAL LOSSES IN POWER REACTOR WINDINGS
}

Journal

Publisher

ISSN

Issue

Pages
Tekhnichna elektrodynamika

Institute of Electrodynamics National Academy of Science of Ukraine 1607-7970 (print), 2218-1903 (online)

No 4, 2020 (July/August)

$67-71$

\section{Authors}

A.H. Hoevenaars ${ }^{1 *}$, A.V. Lavreniuk ${ }^{1 * *}$, I.V. Pentegov ${ }^{2 * \star *}$, S.V. Rymar $^{2 * \star *}$, V.M. Sydorets ${ }^{2 *}$ $\star \star \star \star * *$

1- MIRUS International Inc.,

31 Sun Pac Blvd., Brampton, Canada L6S 5P6,

e-mail: mirus@mirusinternational.com

2. Paton Welding Institute National Academy of Sciences of Ukraine,

11, K. Malevicha str., Kyiv, 03680, Ukraine,

e-mail: sydorvn@gmail.com

* ORCID ID : https://orcid.org/0000-0003-0643-5219

** ORCID ID : https://orcid.org/0000-0002-5632-6873

*** ORCID ID : https://orcid.org/0000-0002-0223-4594

**** ORCID ID : https://orcid.org/0000-0003-0490-4608

***** ORCID ID : https://orcid.org/0000-0002-8498-4726

\section{Abstract}

An approach to reduce the additional losses from eddy and circulating currents in the windings of power reactors with non-magnetic multi-gaps in the legs of the magnetic cores is proposed. The approach is based on variations of the values of non-magnetic gaps and their distribution along the leg - decrease of the gaps occurs from the center of the leg to its edges, and decrease of the distance between the gaps takes place from the edges to the center of the leg. As a result, the magnetic leakage fluxes between the legs of the magnetic core are reduced, and additional losses in the windings and their heating are reduced, accordingly. Due to this, expenses on the active materials and the cost of rectors are reduced and efficiency is increased, which increases their competitiveness in the market of electrical equipment. The advantages of the proposed approach are especially effective for reactors while the higher 
current harmonics present, in particular, for passive filter reactors. References 9, figure 1.

Key words: electrical apparatus, reactors, magnetic circuits, magnetic fluxes of scattering, non-magnetic gaps, additional losses, energy conservation.

Received: 04.03.2020

Accepted: 01.04.2020

Published: 26.06.2020

\section{References}

1. Leites L.V. Electromagnetic calculations of transformers and reactors. Moskva: Energiya, 1981. 392 p. (Rus)

2. Sergeenkov B.N., Kiselev V.M., Akimova N.A. Electric machinery: Transformers. Moskva: Vysshayi Shkola, 1989. 352 p. (Rus)

3. Farbis M., Hoevenaars A.H., McGraw M. Marine Duty Harmonic Mitigation on DC Propulsion Saves Oil Service Vessel Program. IEEE Transactions on Industry Applications. 2017. Vol. 53. Issue 2. Pp. 1617-1626. DOI:

https://doi.org/10.1109/TIA.2016.2621102

4. Hoevenaars A.H., McGraw M., Alexander J. Right-Sizing Generators through Harmonic Mitigation Realizes Energy, Emissions, and Infrastructure Reductions. IEEE Transactions on Industry Applications

2017. Vol. 53. Issue 1. Pp. 675- 683. DOI:

https://doi.org/10.1109/TIA.2016.2603143

5. Farbis M., Hoevenaars A.H., Greenwald J.L. Oil Field Retrofit of ESPs to Meet Harmonic Compliance. IEEE Transactions on Industry Applications. 2016. Vol. 52. Issue 1. Pp. 718-728.

DOI: https://doi.org/10.1109/TIA.2015 .2481358

6. Lammeraner J., Stafl M. Eddy currents. Moskva-Leningrad: Energiya, 1967. 208 p. (Rus)

7. Turowski J. Technical electrodynamics. Moskva: Energiya, 1974. 488 p. (Rus)

8. Voldek A.I. Electrical machines. Leningrad: Energiya, 1974. 840 p. (Rus)

9. Abe T., Hamakake H., Kikuchi K. Reactor Core and Reactor. Patent US № 20100171580 A1. 2010. 
$\underline{\text { PDF }}$

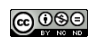

This work is licensed under a Creative Commons Attribution-NonCommercial-NoDerivatives 4.0 International License 